\title{
L-3- $n$-Butylphthalide Improves Cognitive Impairment and Reduces Amyloid- $\beta$ in a Transgenic Model of Alzheimer's Disease
}

\author{
Ying Peng, ${ }^{1,2}$ Jing Sun, ${ }^{1}$ Stephanie Hon, ${ }^{1}$ Alyssa N. Nylander, ${ }^{1}$ Weiming Xia, ${ }^{1}$ Yipu Feng, ${ }^{2}$ Xiaoliang Wang, ${ }^{2}$ \\ and Cynthia A. Lemere \\ ${ }^{1}$ Center for Neurologic Diseases, Brigham and Women's Hospital, Harvard Medical School, Boston, Massachusetts 02115, and 2Institute of Materia Medica, \\ Chinese Academy of Medical Sciences and Peking Union Medical College, Beijing 100050, China
}

\begin{abstract}
Alzheimer's disease (AD) is an age-related, progressive neurodegenerative disorder that occurs gradually and results in memory, behavior, and personality changes. L-3- $n$-butylphthalide (L-NBP), an extract from seeds of Apium graveolens Linn (Chinese celery), has been demonstrated to have neuroprotective effects on ischemic, vascular dementia, and amyloid- $\beta$ (A $\beta$ )-infused animal models. In the current study, we examined the effects of L-NBP on learning and memory in a triple-transgenic AD mouse model (3xTg-AD) that develops both plaques and tangles with aging, as well as cognitive deficits. Ten-month-old 3xTg-AD mice were given $15 \mathrm{mg} / \mathrm{kg} \mathrm{L}-\mathrm{NBP}$ by oral gavage for 18 weeks. L-NBP treatment significantly improved learning deficits, as well as long-term spatial memory, compared with vehicle control treatment. L-NBP treatment significantly reduced total cerebral A $\beta$ plaque deposition and lowered $\mathrm{A} \beta$ levels in brain homogenates but had no effect on fibrillar $\mathrm{A} \beta$ plaques, suggesting preferential removal of diffuse $\mathrm{A} \beta$ deposits. Furthermore, we found that $\mathrm{L}-\mathrm{NBP}$ markedly enhanced soluble amyloid precursor protein secretion ( $\alpha$ APPs), $\alpha$-secretase, and PKC $\alpha$ expression but had no effect on steady-state full-length APP. Thus, L-NBP may direct APP processing toward a non-amyloidogenic pathway and preclude A $\beta$ formation in the 3xTg-AD mice. The effect of L-NBP on regulating APP processing was further confirmed in neuroblastoma SK-N-SH cells overexpressing wild-type human $\mathrm{APP}_{695}$ (SK-N-SH APPwt). L-NBP treatment in 3xTg-AD mice also reduced glial activation and oxidative stress compared with control treatment. L-NBP shows promising preclinical potential as a multitarget drug for the prevention and/or treatment of Alzheimer's disease.
\end{abstract}

\section{Introduction}

Alzheimer's disease $(\mathrm{AD})$ is the most common form of senile dementia, characterized by progressive memory loss. Neuropathological hallmarks of $\mathrm{AD}$ include extracellular senile plaques and intracellular neurofibrillary tangles (Selkoe, 1994). Amyloid- $\beta$ protein $(\mathrm{A} \beta)$, the core of senile plaque, is a $39-43$ amino acid peptide; $\mathrm{A} \beta$ oligomers and aggregates are considered to play a central role in the onset and progression of AD (Chen et al., 2000; Walsh et al., 2002). $A \beta$ is derived by proteolysis of an integral membrane protein known as the amyloid precursor protein (APP) (Kang et al., 1987). APP is a single-pass transmembrane protein and can be cleaved in at least two pathways: amyloidogenic and nonamyloidogenic. The amyloidogenic pathway involves $\beta$ - and $\gamma$-secretase, cleaving APP at the $\mathrm{N}$ and $\mathrm{C}$ termini of $\mathrm{A} \beta$, respectively, and releasing $\mathrm{A} \beta$ into the extracellular space (Haass et al., 1992; Shoji et al., 1992). The alternative pathway involves activa-

Received Jan. 20, 2010; revised April 8, 2010; accepted April 30, 2010

This work was supported by Alzheimer's Association Grant IIRG-06-27532 (C.A.L.). We thank Dr. Guiquan Chen for help with experiments and Dr. Frank M. Laferla for providing 3xTg-AD mouse breeders. We also thank Dr. Peter Davies for the generous gift of the antibodies used in these studies.

Correspondence should be addressed to Dr. C. A. Lemere, Center for Neurologic Diseases, Harvard New Research Building, Room 636F, 77 Avenue Louis Pasteur, Boston, MA 02115. E-mail: clemere@rics.bwh.harvard.edu

DOI:10.1523/JNEUROSCI.0340-10.2010

Copyright $\odot 2010$ the authors $\quad 0270-6474 / 10 / 308180-10 \$ 15.00 / 0$ tion of $\alpha$-secretase, now believed to be a member of the disintegrin and metalloprotease (ADAM) families (Lammich et al., 1999; Slack et al., 2001). This processing cleaves APP within the sequence of $\mathrm{A} \beta$ peptide, releasing a soluble APP fragment ( $\alpha$ APPs) into the extracellular media, thereby precluding the formation of A $\beta$ (Esch et al., 1990; Sisodia et al., 1990). The $\alpha$ APPs fragment has been shown to have both neurotrophic (Wallace et al., 1997) and neuroprotective (Mattson et al., 1993; SmithSwintosky et al., 1994; Gralle et al., 2009) activities. Recent studies suggest that $\alpha$ APPs might serve as an AD therapeutic target (Etcheberrigaray et al., 2004; Small et al., 2005; Turner et al., 2007).

L-3-n-Butylphthalide (L-NBP) was extracted as a pure component from seeds of Apium graveolens Linn, Chinese celery. Afterward, DL-3- $n$-butylphthalide was synthesized and approved by the State Food and Drug Administration of China for clinical use in stroke patients in 2002. NBP is a chiral compound and contains $\mathrm{L}$ and $\mathrm{D}$ isomers that have been recently isolated and synthesized. Previous studies showed that L-NBP significantly improved microcirculation in pial arterioles (Xu and Feng, 1999), reduced the area of cerebral infarct and inhibited platelet aggregation (Peng et al., 2004, 2005), improved mitochondrial function and decreased oxidative damage (Dong and Feng, 2002), reduced neuronal apoptosis (Chang and Wang, 2003), and inhibited increases in intracellular calcium levels and the inflammatory re- 
Table 1. Primary antibodies used in this study

\begin{tabular}{|c|c|c|c|c|c|}
\hline Antibody & Immunogen & Host & Dilution & Application & Source \\
\hline R1736 & Residues 595-611 of APP695 ( $\alpha$ APPs) & Rabbit & $1: 1000$ & WB & D. Selkoe (Center for Neurologic Diseases, Boston, MA) \\
\hline $\mathrm{R} 1282$ & $A \beta_{1-40}$ & Rabbit & $1: 1000$ & $\mathrm{IHC}$ & D. Selkoe \\
\hline C8 & Against last 20 C-terminal residues of APP & Rabbit & $1: 1000$ & WB & D. Selkoe \\
\hline IDE-1 & Residues $62-73$ of human IDE-1 & Rabbit & $1: 1000$ & WB & D. Selkoe \\
\hline $\operatorname{PKC} \alpha$ & C terminus of PKC $\alpha$ of human origin & Mouse & $1: 1000$ & WB & Santa Cruz Biotechnology \\
\hline ADAM10 & Residues 732-748 of human ADAM10 & Rabbit & $1: 200$ & WB & Sigma \\
\hline TACE & C terminal of human TACE & Rabbit & $1: 200$ & WB & Prosci \\
\hline CD45 & Mouse B-cells & Rat & $1: 5000$ & $\mathrm{IHC}$ & Serotec \\
\hline GFAP & Bovine GFAP & Rabbit & $1: 1000$ & $\mathrm{IHC}$ & Dako \\
\hline AT8 & Phospho-Ser202/Thr205 & Mouse & $1: 25$ & IF & Pierce \\
\hline AT180 & Phospho-Thr231/Ser235 & Mouse & $1: 50$ & IF & Pierce \\
\hline PHF-1 & Phospho-Ser396/Ser404 & Mouse & $1: 100$ & IF & P. Davies (Albert Einstein College of Medicine, Bronx, NY) \\
\hline
\end{tabular}

IHC, Immunohistochemistry; IF, immunofluorescent staining; WB, Western blot.

sponse (Xu and Feng, 2000) in experimental ischemic animal models. Recently, we found that L-NBP alleviated the learning and memory deficits induced by chronic cerebral hypoperfusion in rats (Peng et al., 2007b). In A $\beta$ intracerebroventricularly infused rats, oral gavage with L-NBP significantly improved cognitive impairment and inhibited oxidative injury, neuronal apoptosis, and glial activation (Peng et al., 2009). Furthermore, in primary neurons and neuroblastoma SH-SY5Y cells, L-NBP attenuated $\mathrm{A} \beta$-induced neuronal apoptosis (Peng et al., 2008). These results suggest that L-NBP might have potential as an AD therapeutic.

In this study, we examined the effect of L-NBP on cognitive impairment in a triple-transgenic mouse model of AD (3xTg-AD mice). Moreover, we investigated the mechanisms underlying the efficacy of the compound (e.g., APP processing, A $\beta$ generation and clearance, and glial activation).

\section{Materials and Methods}

Animals and treatment. L-NBP (purity $>98 \%$ ) was synthesized by the Department of Medical Synthetic Chemistry, Institute of Materia Medica and dissolved in vegetable oil at a concentration of $15 \mathrm{mg} / \mathrm{ml}$. In this study, 3xTg-AD mice expressing mutant human genes APPswe, $\mathrm{PS}_{\mathrm{M} 146 \mathrm{~V}}$, and tau $\mathrm{P} 301 \mathrm{~L}_{\mathrm{L}}$ generated by Dr. Frank M. LaFerla (University of California at Irvine, Irvine, CA) were used (Oddo et al., 2003a). The mice were originally generated in a hybrid 129/C57BL/6 genetic background but were backcrossed for multiple generations onto a C57BL/6 single background. In this model, intracellular $A \beta$ is apparent between 3 and 6 months of age, and $\mathrm{A} \beta$ deposition is evident by 12 months of age. Longterm potentiation is severely impaired in 6-month-old mice (Oddo et al., $2003 \mathrm{~b}$ ). In addition, the $3 \mathrm{xTg}-\mathrm{AD}$ mice have been shown to exhibit cognition impairment by 6 months of age (Billings et al., 2005). Therefore, we treated $3 \times \mathrm{xTg}-\mathrm{AD}$ mice for 18 weeks, starting at 10 months of age, assuming these mice had already developed cognitive impairment, as published previously. However, since our study was conducted, a genetic drift has been observed in this line of mice outside of the LaFerla laboratory (Hirata-Fukae et al., 2008). At the time of our study, the 3xTg-AD mice in our colony developed plaque deposition between 10 and 12 months, but we did not run a pretest to determine whether they were already cognitively impaired before the onset of L-NBP treatment.

The 3xTg-AD mice were divided into two groups: one received L-NBP treatment and the other received vegetable oil alone (vehicle control group). L-NBP was administered by oral gavage $5 \mathrm{~d}$ /week at a dose of 15 $\mathrm{mg} / \mathrm{kg}$ body weight ( $n=8$, four males and four females). A control group ( $n=9$, five males and four females) received oral gavage in the same manner using vegetable oil without L-NBP. The body weight of each mouse was recorded every 2 weeks. After behavioral testing was completed, the mice were killed by $\mathrm{CO}_{2}$ inhalation, and blood was collected by cardiac puncture, followed by transcardial perfusion with $20-30 \mathrm{ml}$ PBS. The brain was removed. One hemibrain was snap frozen in liquid nitrogen and stored at $-80^{\circ} \mathrm{C}$ until analysis, and the other hemibrain was fixed in $4 \%$ paraformaldehyde for $2 \mathrm{~h}$, followed by incubation in graded sucrose at $4^{\circ} \mathrm{C}$. All animal use was approved by the Harvard Standing Committee for Animal Use and was in compliance with all state and federal regulations.

Morris water maze. The Morris water maze task was used to evaluate the drug-related changes in learning and memory in mice (Morris, 1984). Briefly, the apparatus consisted of a circular metal pool $(160 \mathrm{~cm}$ in diameter) filled with water made opaque by the addition of white beads. A translucent acrylic platform ( $10 \mathrm{~cm}$ in diameter), located in the center of the northwest or southeast quadrant, was placed $1.5 \mathrm{~cm}$ under the surface of the water. There were prominent visible cues around the room. The mouse was gently released with its nose against the wall into the water from one of the four preplanned starting positions (north, south, east, or west). The swimming path of each mouse was tracked using Watermaze 2020 software (HVS Image).

Spatial learning training. Spatial training of the hidden platform in the water maze was performed for 5 consecutive days. On each day, training consisted of three blocks, with each interblock interval being $2 \mathrm{~h}$. In each block, there were two consecutive training trials, and the intertrial interval was $15 \mathrm{~s}$. The starting position for each trial was pseudorandomly chosen and counterbalanced across all the experimental groups. The mice were given a maximum of $60 \mathrm{~s}$ to find the hidden platform. If a mouse failed to find the platform within $60 \mathrm{~s}$, the training was terminated, a maximum score of $60 \mathrm{~s}$ was assigned, and the mouse was manually guided to the hidden platform. The mouse was allowed to stay on the platform for $30 \mathrm{~s}$ before it was removed from the pool.

Probe trial. Two probe trials were performed, one at $2 \mathrm{~h}$ and another at $48 \mathrm{~h}$ after the last training trial (day 5), to assess short-term and longterm memory consolidation, respectively. The platform was removed and the mice were placed into the pool from the quadrant opposite to the training quadrant. Starting positions were counterbalanced across mice. In each probe trial, the mice were allowed to swim for $60 \mathrm{~s}$.

Immunohistochemistry and histology. Ten micrometer sagittal cryosections of mouse brain were mounted on glass slides. The primary antibodies used in the study are summarized in Table 1. Secondary biotinylated antibodies (anti-mouse, anti-rat, and anti-rabbit) and secondary antibodies for immunofluorescent staining were obtained from Vector Laboratories and Invitrogen. Immunohistochemical staining was performed as described previously, with the hippocampus as region of interest (ROI) (Maier et al., 2008). Thioflavin S (Thio S) staining for fibrillar A $\beta$ was performed by incubating slides in a $1 \%$ aqueous solution of Thioflavin S for $10 \mathrm{~min}$, followed by rinsing in 80 and 95\% ethanol and then distilled water. For immunofluorescent staining with AT8, AT180, and PHF-1, sections were first pretreated with $0.01 \mathrm{~m}$ Tris-buffered saline (TBS) and then blocked with $2 \%$ goat serum in TBS for $5 \mathrm{~min}$. The sections were incubated with the primary antibodies overnight at $4^{\circ} \mathrm{C}$, followed by secondary antibodies (1:200 in TBS plus $2 \%$ goat serum) for $2 \mathrm{~h}$ at room temperature. To quantify immunoreactivity and Thioflavin $S$ staining, acquisition of images was performed in a single session using a QICAM camera (Q-imaging) mounted on an Olympus BX50 microscope. Image analysis was performed using IP Lab Spectrum 3.1 Image 
Analyzer software. The threshold of detection was held constant during analysis. For all treatment groups, the percentage area occupied by $\mathrm{A} \beta$, Thio S, and glial immunoreactivity in the hippocampal area, including CA regions, dentate gyrus, and dorsal subiculum, was calculated for three equidistant sections per mouse, whereas phosphorylated tau immunoreactivity in the same hippocampal regions was calculated for four equidistant sections per mouse.

Western blot. The brains were homogenized in 5 vol of TBS with a protease inhibitor cocktail (Roche Applied Science) and phosphatase inhibitors (50 mu sodium fluoride, $2 \mathrm{~mm}$ sodium orthovanadate, and 10 mu sodium pyrophosphase). The samples were centrifuged at 175,000 $\times$ $g$ for $30 \mathrm{~min}$. The pellets were resuspended in the same volume of TBS-T (TBS/1\% Triton X-100 plus protease inhibitor cocktail and phosphatase inhibitor) buffer, sonicated for $5 \mathrm{~min}$ in $4^{\circ} \mathrm{C}$ water bath, homogenized, and centrifuged at $175,000 \times g$ for $30 \mathrm{~min}$ at $4^{\circ} \mathrm{C}$. The supernatant of the TBS-T-soluble homogenate was collected and stored at $-20^{\circ} \mathrm{C}$. The pellets were extracted a third time as described previously (Johnson-Wood et al., 1997) using ice-cold guanidine buffer (5 $\mathrm{m}$ guanidine- $\mathrm{HCl} / 50 \mathrm{~mm}$ Tris, $\mathrm{pH}$ 8.0). These TBS-insoluble fractions were run on $10-20 \%$ Tricine gels (Invitrogen), transferred onto $0.2 \mu \mathrm{m}$ nitrocellulose membranes at $400 \mathrm{~mA}$ for $2 \mathrm{~h}$, and then blocked with $5 \%$ fat-free milk in 20 $\mathrm{mmol} / \mathrm{L}$ Tris- $\mathrm{HCl}$, pH 7.4, containing $150 \mathrm{mmol} / \mathrm{L} \mathrm{NaCl}$ and $0.05 \%$ Tween-20 for $2 \mathrm{~h}$ at room temperature. Then, the blots were probed with primary antibodies overnight at $4^{\circ} \mathrm{C}$, followed by incubation with enhanced chemiluminescence (ECL) anti-rabbit or anti-mouse IgG horseradish peroxidase-linked species-specific whole antibody for $2 \mathrm{~h}$ at room temperature. The signal was detected using an ECL kit, scanned, and analyzed by densitometric evaluation using an imaging system and analyzing software (FluorchemTMIS-8800 software; Alpha Innotech). Membranes were reprobed with an antibody against $\beta$-actin as a control for protein loading.

Antioxidative assay. Malondialdehyde (MDA), the most abundant lipid peroxide, is widely used to measure lipid peroxidation as an indicator of oxidative stress. MDA levels of brain homogenates were examined by using a BIOOXYTECH MDA-586 kit (Oxis Research) according to the instructions of the manufacturer. In addition, we measured the activities of total antioxidant enzymes and catalase using a BIOXYTECHAOP-450 kit and a BIOXYTECHCatalase-520 kit (Oxis Research), respectively.

Cell culture. Human neuroblastoma SK-N-SH cells overexpressing wild-type APP695 (SK-N-SH APPwt) were a gift from Dr. Dennis Selkoe (Center for Neurologic Diseases, Boston, MA). SK-N-SH APPwt were grown in DMEM containing 10\% fetal bovine serum, $100 \mu \mathrm{g} / \mathrm{ml}$ penicil-

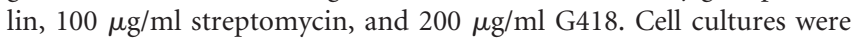
incubated at $37^{\circ} \mathrm{C}$ in a humid $5 \% \mathrm{CO}_{2} / 95 \%$ air environment. Cells were grown until nearly confluent, washed with serum-free medium, and incubated in serum-free medium for $18-24 \mathrm{~h}$. For detection of $\alpha \mathrm{APPs}$, full-length APP, $\mathrm{A} \beta, \mathrm{ADAMs}$, protein kinase $\mathrm{C} \alpha(\mathrm{PKC} \alpha)$, and cell viability, the cells were incubated with L-NBP for $24 \mathrm{~h}$. In addition, in the other determinations, cells were preincubated with ADAMs and PKC inhibitors for $30 \mathrm{~min}$ and then coincubated with L-NBP plus inhibitor for $24 \mathrm{~h}$. After incubation with the drugs or control treatments for the indicated periods, conditioned media were collected and mixed with a complete protease inhibitor cocktail (Roche Applied Science). The media were centrifuged at $3000 \times g$ for $10 \mathrm{~min}$ to remove cellular debris. Supernatants were concentrated with Amicon Ultra-4 centrifugal filter devices (Millipore Corporation). The concentrated conditioned medium was stored at $-20^{\circ} \mathrm{C}$. Cells were washed twice with ice-cold PBS and lysed with $500 \mu \mathrm{l}$ of $1 \% \mathrm{NP}-40$ in $50 \mathrm{mmol} / \mathrm{L}$ Tris $\mathrm{HCl}, \mathrm{pH}$ 7.6, $150 \mathrm{mmol} / \mathrm{L}$ $\mathrm{NaCl}, 2 \mathrm{mmol} / \mathrm{L}$ EDTA, and complete protease inhibitor mixture as described previously (Peng et al., 2007a). Aliquots of lysates were spun at $14,000 \mathrm{rpm}$ for $10 \mathrm{~min}$, and the supernatants were stored at $-20^{\circ} \mathrm{C}$. To ensure equal loading, protein levels were determined using the DC Protein Assay (Bio-Rad).

Cell viability. Cell viability was evaluated using a Cell Viability kit (Promega) according to the instructions of the manufacturer. Cells were cultured in 96-well plates. After treatment with L-NBP or control treatment for $24 \mathrm{~h}, 15 \mu \mathrm{l}$ of dye solution was added to each well. The plate was incubated at $37^{\circ} \mathrm{C}$ for $4 \mathrm{~h}$ in a humidified, $5 \% \mathrm{CO}_{2}$ atmosphere. Then,
$100 \mu \mathrm{l}$ of the solubilization solution was added to each well, and the plates were allowed to stand overnight at room temperature to completely solubilize the formazan crystals. The absorbance was recorded at a $570 \mathrm{~nm}$ wavelength using a 96-well plate reader.

ELISA for A $\beta$ levels. A $\beta$ levels were measured in the conditioned medium of SK-N-SH APPwt cells and brain homogenates (TBS-, TBS-T-, and guanidine-soluble fractions) using specific $A \beta_{x-40}, A \beta_{x-42}$, and $A \beta_{1-\text { total }}$ ELISAs as reported previously (Peng et al., 2006).

Statistical analysis. Prism software (GraphPad Software) was used to analyze the data. All data were expressed as mean \pm SEM. A value of $p<$ 0.05 was considered statistically significant. Treatment differences in the escape latency in the water maze task were analyzed using repeatedmeasures ANOVA. The chance performance of probe trial in the water maze was analyzed by one-sample $t$ test. In addition, treatment differences in the probe trials and biochemical and pathological assays were analyzed using the Mann-Whitney $U$ test. The in vitro studies were analyzed using a one-way ANOVA, followed by a Newman-Keuls post hoc test. Each of the in vitro experiments was repeated three to six times.

\section{Results}

\section{Oral L-NBP treatment ameliorated the spatial learning and some memory deficits in 3xTg-AD mice}

We carefully monitored the general health of $3 x \mathrm{Tg}-\mathrm{AD}$ mice during L-NBP treatment and did not find any abnormal changes. In addition, the body weights of mice were not significantly different between L-NBP-treated and vehicle control mice (data not shown). Together, these data indicate that L-NBP had no significant toxicity in mice.

After L-NBP treatment, at the age of 15 months, the 3xTg-AD mice were tested behaviorally. Morris water maze test, one of the most widely accepted behavioral tests of hippocampal-dependent spatial learning and memory (Morris, 1984), was used to monitor the spatial learning and memory in the mice. Spatial learning was assessed by the time required to find the hidden platform (escape latency). Figure $1 A$ shows the results of all mice during water maze acquisition training. Repeated-measures ANOVA revealed a significant day effect on escape latency $\left(F_{(4,60)}=14.76 ; p<0.001\right)$ within the groups, suggesting that all L-NBP-treated mice improved their spatial learning effectively across the $5 \mathrm{~d}$ training period. In addition, we found a significant treatment effect $\left(F_{(1,15)}=5.72\right.$; $p<0.05$ ) on the escape latency demonstrating that L-NBP was effective in attenuating spatial learning deficits in $3 \mathrm{xTg}$-AD mice.

Furthermore, we investigated the effects of L-NBP on spatial memory deficits in 3xTg-AD mice. Probe trials were conducted to assess the short-term memory at $2 \mathrm{~h}$ and long-term memory at $48 \mathrm{~h}$ after training on day 5 and day 7, respectively (Fig. 1C). Vehicle control mice did not spend significantly more time searching for the platform in the target quadrant (where the platform had been located previously) relative to chance performance (25\%). However, L-NBP-treated mice spent significantly more time searching in the target quadrant relative to chance performance in both the $2 \mathrm{~h}$ short-term and $48 \mathrm{~h}$ long-term memory tests $(45.3 \pm 9.49 \%, p<0.05$ and $57.15 \% \pm 7.81 \%, p<$ 0.001 , respectively; one-sample two-tailed $t$ test). Even so, in the short-term probe trial, the difference in performance between vehicle and L-NBP-treated mice was not significant. In contrast, in the long-term spatial reference memory test, L-NBP-treated mice spent significantly more time in the target quadrant compared with the vehicle control mice $(p<0.05)$. Treatment groups were gender matched and showed no significant gender differences.

To exclude the possibility that the improvement of L-NBP on spatial learning and memory in 3xTg-AD mice was not attribut- 


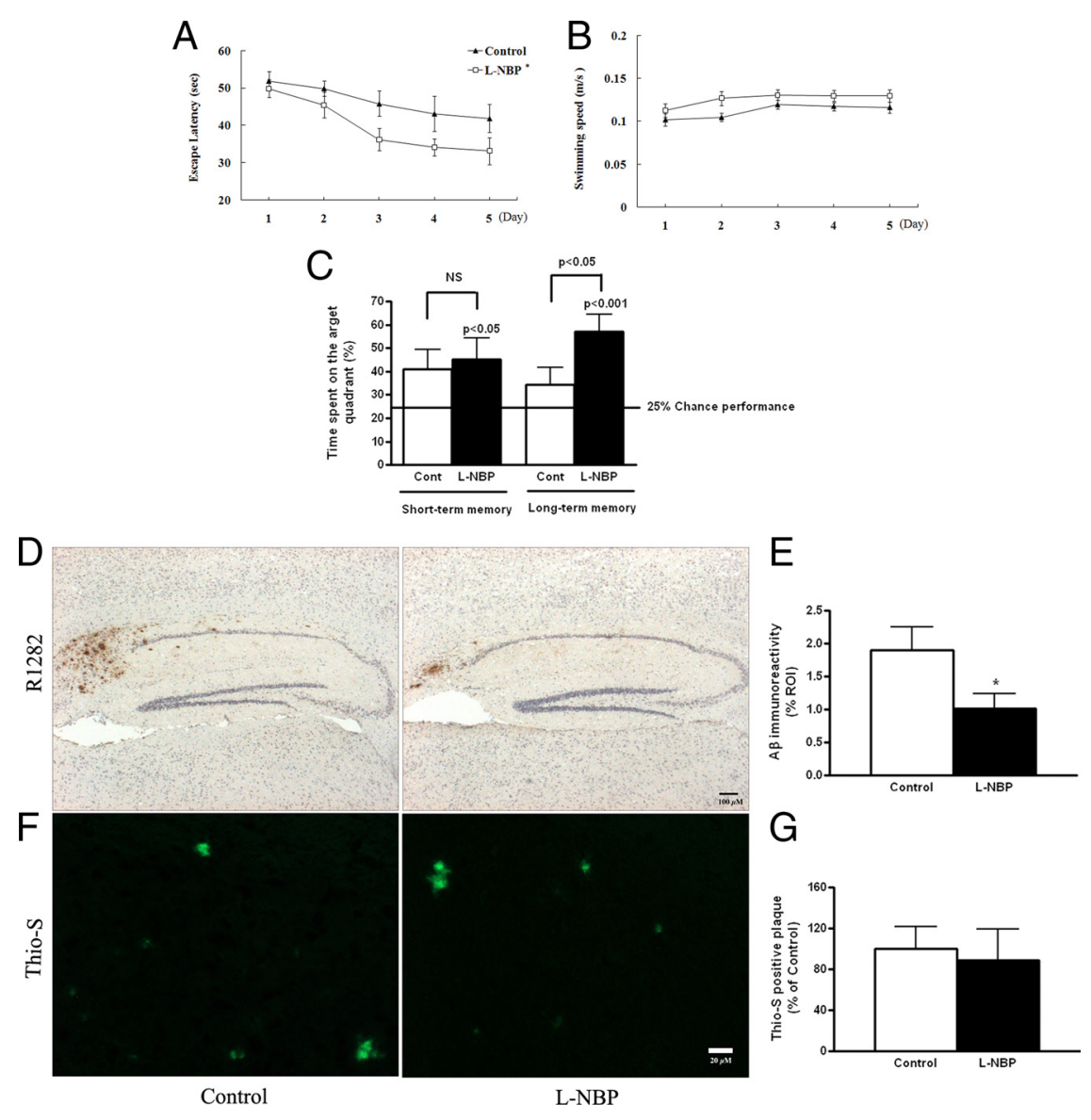

Figure 1. Long-term L-NBP treatment improved spatial learning and memory deficits and reduced total $A \beta$ plaque burden in 3xTg-AD mice. A, Acquisition of spatial learning was assessed in the Morris water maze hidden platform task. Latency score represents the time taken to escape to the platform once the mouse in put in the water. All mice showed significant improvement in escape latency with successive days of training, indicating that the learning deficits in the 3xTg-AD mice were significantly attenuated by L-NBP treatment compared with vehicle control mice. $B$, No significant differences were observed in motor function of the L-NBP-treated mice and the vehicle controls as reflected by the swimming speed. $\boldsymbol{C}$, L-NBP improved short-term (day 5) and long-term (48 h; day 7) memory in the probe trial. L-NBP treatment significantly increased the time spent searching for the hidden platform in the target quadrant compared with $25 \%$ chance performance whether in day 5 and day 7 . Furthermore, compared with the control-treated mouse, L-NBP-treated mice spent significantly more time searching for the hidden platform in the target quadrant on day $7(p<0.05)$. There was no significant difference between L-NBP-treated and control-treated 3xTg-AD mice in short-term spatial memory. D, Total plaque load (including diffuse and compacted fibrillar plaques), using the A $\beta$ antibody R1282, was significantly decreased in the hippocampus of L-NBP-treated 3xTg-AD mice compared with vehicle controls. $\boldsymbol{F}$, Fibrillar, compact plaques labeled by Thioflavin $S$ were not significantly different between treatment groups. $\boldsymbol{E}, \mathbf{G}$, Quantitative image analysis was performed for R1282 immunoreactivity $(\boldsymbol{E})$ and Thioflavin $S(\boldsymbol{G})$. Values represent group mean \pm SEM. Eight to nine mice were tested per group. ${ }^{*} p<0.05$ versus vehicle control group. The horizontal line marks chance performance.

able to sensorimotor abnormalities, we first analyzed swimming ability. As shown in Figure $1 B$, there was no difference on swimming speed between the two groups of mice across the 5 training days. Moreover, we analyzed thigmotaxis, a measure of anxiety level in the water maze, and did not find any evidence of elevated thigmotaxic behavior in either group during the $5 \mathrm{~d}$ training period (data not shown).

To further exclude the possibility that $3 \mathrm{xTg}-\mathrm{AD}$ mice may have developed abnormal basic learning or vision acuity problem, we used a visible cued task to test the same mice in the water maze. The 3xTg-AD mice did not exhibit any impairment in the cue task performance (data not shown). Thus, these results confirmed that the $3 \times \mathrm{Tg}-\mathrm{AD}$ mice display normal basic spatial learning or vision acuity.

\section{L-NBP reduced cerebral plaque deposition and $A \beta$ levels in 3xTg-AD mice}

To determine whether the improvement of L-NBP on the learning and memory deficits correlated with changes in $\mathrm{A} \beta$ levels in the brain, all mice were killed after behavioral testing. The brains were removed for biochemical and immunohistochemical analyses. Total $\mathrm{A} \beta$ plaque load, including diffuse and compacted, fibrillar plaques, was detected by $\mathrm{A} \beta$ immunolabeling with a general $\mathrm{A} \beta$ polyclonal antibody, R1282 (a gift from Dr. D. Selkoe) (Fig. 1D), and fibrillar amyloid deposits by Thioflavin $\mathrm{S}$ staining (Fig. $1 F)$. Long-term oral administration of L-NBP significantly reduced total $\mathrm{A} \beta$ plaque burden in the hippocampus, particularly in the dorsal subiculum $(p<$ 0.05) (Fig. 1E). However, L-NBP had no effect on Thio S-positive plaque deposition, indicating that L-NBP preferentially reduced nonfibrillar, diffuse $\mathrm{A} \beta$ plaques (Fig. $1 G$ ). Next, we analyzed cerebral A $\beta$ levels by ELISA. L-NBP treatment partially lowered $\mathrm{A} \beta$ levels in TBS-soluble, TBS-T-soluble, and guanidine-soluble brain homogenates (Fig. $2 A-I$ ). In particular, significant reductions were observed in TBS-T-soluble $\mathrm{A} \beta_{1 \text {-total }}(p<0.05)$ and guanidine-soluble $\mathrm{A} \beta_{1 \text {-total }}(p<0.01)$ levels in L-NBP-treated mouse brain compared with vehicle controls. In addition, L-NBP had a tendency to lower TBSsoluble $\mathrm{A} \beta_{x-42}$ levels $(p=0.07)$. These data confirm that L-NBP had some $A \beta$ lowering effect in vivo.

\section{L-NBP attenuated glial activation in 3xTg-AD mice}

Activated astrocytes and microglia are associated with $\mathrm{A} \beta$ plaque deposition in the brains of $\mathrm{AD}$ patients and transgenic $\mathrm{AD}$ mouse models (Itagaki et al., 1989; Matsuoka et al., 2001). In our previous study, L-NBP was shown to attenuate astrocyte activation in $\mathrm{A} \beta$ intracerebroventricularly infused rats (Peng et al., 2009). Thus, we investigated the ability of L-NBP treatment to suppress astrocyte and microglial reactivity in the current study. Serial sections were stained with an anti-A $\beta$ antibody (R1282), an anti-GFAP antibody for astrocytes, and an anti-CD45 antibody for microglia (Fig. $3 A$ ). Immunostaining of GFAP showed that reactive astrocytes were abundant and closely associated with $\mathrm{A} \beta$ deposits in $3 \mathrm{xTg}-\mathrm{AD}$ mice. $\mathrm{L}-\mathrm{NBP}$ treatment significantly reduced GFAP immunoreactivity by $31 \%$ compared with vehicle control mice $(p<0.05)$ (Fig. $3 B)$. CD45-immunoreactive activated microglia were evident in and around $\mathrm{A} \beta$ plaque deposits in $3 \mathrm{xTg}-\mathrm{AD}$ mice. Overall, activated microglia were reduced by $\sim 30 \%$ in the L-NBP-treated mice relative to the vehicle control mice, but the difference was not significant (Fig. $3 \mathrm{C}$ ), possibly because of the high variability observed between animals within groups. 
L-NBP directed APP processing toward the non-amyloidogenic pathway in 3xTg-AD mice

Our data demonstrated that L-NBP treatment attenuated cognitive impairment and lowered $\mathrm{A} \beta$ plaque deposition and $\mathrm{A} \beta$ levels in the brain. To identify the underlying mechanism, we investigated the effect of L-NBP on APP processing, $\alpha$ APPs, and fulllength APP by Western blot measurement. We chose the polyclonal antibody R1736 (a gift from Dr. D. Selkoe), which was raised in rabbits against residues 595-611 of APP695 and labels $\alpha$ APPs as a $98 \mathrm{kDa}$ band and full-length APP at $\sim 110 \mathrm{kDa}$. L-NBP treatment significantly stimulated the release of $\alpha$ APPs $(p<0.05)$ (Fig. $4 A, B)$, suggesting that L-NBP may mediate APP processing toward the nonamyloidogenic pathway. It has been reported that increased APP synthesis may lead to elevated APP secretion. Therefore, we next determined the effect of L-NBP on full-length APP levels by using the C-terminal APP polyclonal antibody C8 (a gift from Dr. D. Selkoe). L-NBP treatment had no effect on APP steady-state levels, further suggesting that L-NBP affected APP processing but not APP synthesis (Fig. $4 A, B$ ).

ADAM family enzymes catalyze the shedding of the ectodomain of APPs and other membrane proteins (Allinson et al., 2003). ADAM 10 and ADAM17 were examined in the current study because of their relevance to Alzheimer's disease (Buxbaum et al., 1998; Lammich et al., 1999). L-NBP treatment significantly increased ADAM10 and ADAM17 levels (Fig. 4A). Quantitative analysis showed a $50 \%$ elevation in ADAM10 levels $(p<0.01)$ and a $70 \%$ increase in ADAM17 levels $(p<0.05)$ after L-NBP treatment (Fig. $4 C$ ). These data provide additional evidence that L-NBP may mediate APP processing via the $\alpha$-secretase pathway.

Reduced $\mathrm{A} \beta$ levels may also reflect $\mathrm{A} \beta$ degradation. Insulin degrading enzyme (IDE) is one of the main proteolytic enzymes responsible for cerebral A $\beta$ degradation (Farris et al., 2003). Using a specific IDE polyclonal antibody (a gift from Dr. D. Selkoe) for Western blotting, we found that L-NBP-treated mice showed a nonsignificant trend for increased IDE expression in the brain compared with vehicle control mice $(p=0.08)$ (Fig. $4 A, C)$. Thus, it might be possible that L-NBP lowering of A $\beta$ burden may be attributable, in part, to modest acceleration of $A \beta$ degradation, although additional studies in a larger number of mice are needed to confirm this very preliminary finding.

A number of reports indicate that $\mathrm{PKC}$ is involved in the regulation of APP processing (Nitsch et al., 1992; Peng et al., 2007a). PKC agonist phorbol esters have been shown to increase $\alpha$ APPs release and decrease A $\beta$ levels (Checler, 1995; Chen and Fernandez, 2004). In particular, PKC $\alpha$ has been demonstrated to be involved in non-amyloidogenic cleavage of APP (Kinouchi et al., 1995). PKC $\alpha$ was assessed by Western blot. As shown in Figure 4, $A$ and $B$, a significant $33 \%$ increase in PKC $\alpha$ expression was observed in L-NBP-treated mice compared with vehicle control mice $(p<0.05)$, indicating that L-NBP might enhance PKC $\alpha$ control group.
B

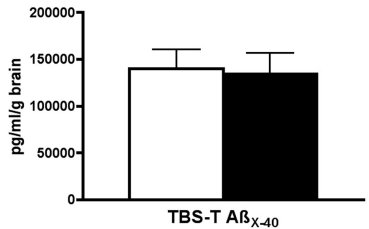

E

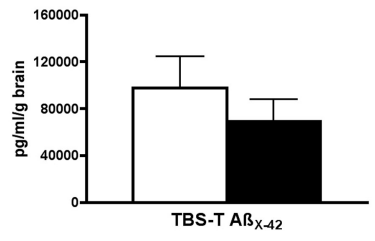

$\mathrm{H}$
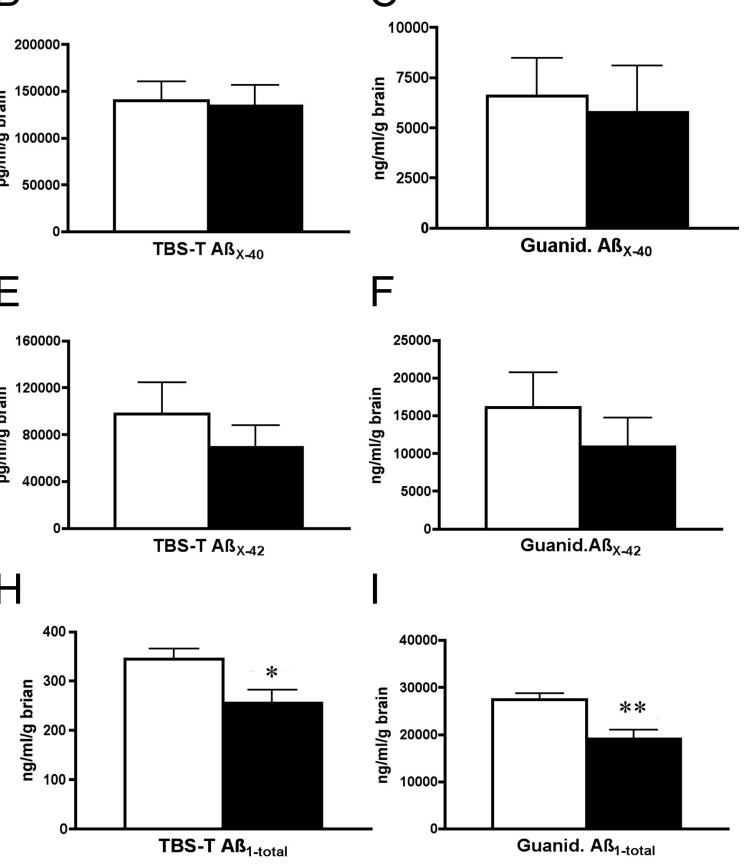

F

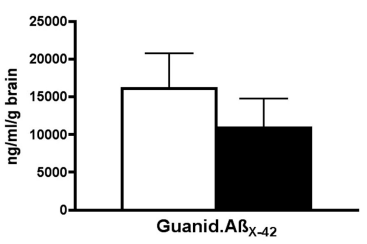

I

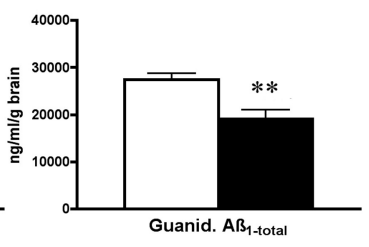

Figure 2. $\quad$ L-NBP treatment demonstrated some $A \beta$-lowering effects in brain homogenates of L-NBP-treated mice (black bars) with vehicle control-treated mice (white bars) using $A \beta$-specific ELISAs $(\boldsymbol{A}-\boldsymbol{I})$. $\boldsymbol{A}-\boldsymbol{C}, A \beta_{x-40}$ levels were not changed after L-NBP treatment. $D-F, A \beta_{x-42}$ levels of brain homogenates showed a trend $(p<0.07)$ for lower $A \beta_{x-42}$ levels in TBS-soluble 列 homogenates $(p<0.01)$. Values represent group mean \pm SEM. $n=8-9$ mice per group. ${ }^{*} p<0.05,{ }^{* *} p<0.01$ versus vehicle

signaling, thereby directing APP processing toward to nonamyloidogenic pathway.

L-NBP decreased oxidative stress in 3xTg-AD mice

In the 3xTg AD mouse model, it had been demonstrated that oxidative stress occurs at an early stage, before the appearance of $\mathrm{A} \beta$ plaques and neurofibrillary tangles (Resende et al., 2008). MDA, a lipid peroxidation end product, is an indicator of oxidative stress (Jackson, 1999). In this study, the MDA levels of the brain were examined by spectrophotometric assay. MDA levels were significantly reduced in L-NBP-treated mice compared with vehicle control mice $(p<0.05)$, suggesting that L-NBP may prevent oxidative stress injury. Modest and nonsignificant increases in total antioxidants and catalase were observed in L-NBP-treated 3xTg-AD mice compared with control-treated mice (data not shown).

L-NBP modestly lowered AT8 phosphorylated tau immunoreactivity but overall had no significant effect on tau protein phosphorylation

Hyperphosphorylated tau appears in the 3xTg-AD mouse brain after the onset of $\mathrm{A} \beta$ deposition (Oddo et al., 2003b). In an $\mathrm{A} \beta$ intracerebroventricularly infused rat model, we found that L-NBP reduced tau abnormal hyperphosphorylation by inhibiting glycogen synthase kinase-3 $\beta$ activity (Peng et al., 2009). Given the beneficial effects of L-NBP on lowering A $\beta$ deposition and regulating APP processing, we explored a possible role of $\mathrm{L}-\mathrm{NBP}$ in tau protein hyperphosphorylation in 3xTg-AD mice. Tau hyperphosphorylation was determined by immunofluorescent staining using specific antibodies against different phosphorylation sites on tau, including monoclonal antibodies: AT8 


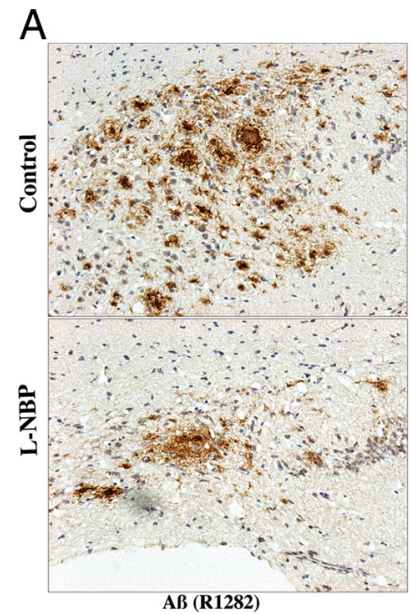

A
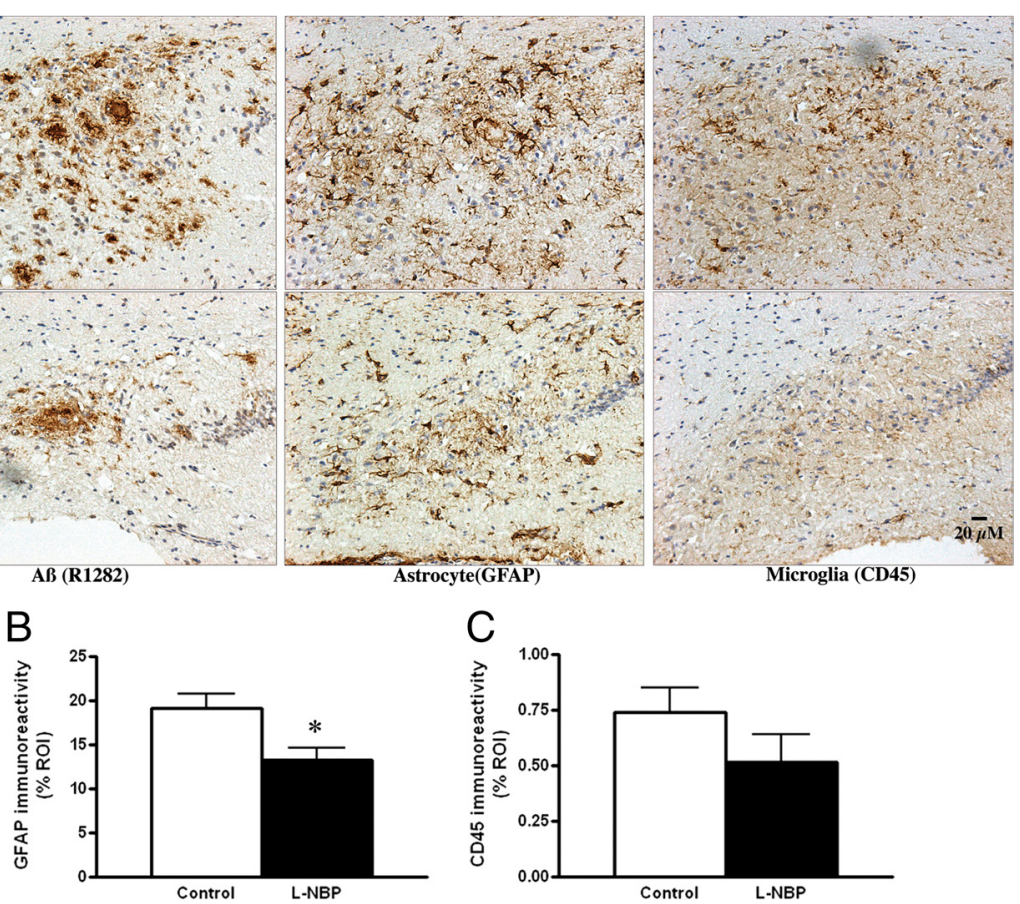

Figure 3. L-NBP treatment reduced glial activation in the hippocampi of 3xTg-AD mice. $A$, Immunohistochemical analysis of hippocampus of representative serial sections of a vehicle control-treated animal (top) and an L-NBP-treated animal (bottom). L-NBP reduced the total plaque load. In parallel, the number of GFAP-positive astrocytes and CD45-positive microglia were also decreased after chronic L-NBP treatment. B, Quantitative image analysis of GFAP immunoreactivity demonstrated that reactive astrocytes were significantly decreased in L-NBP-treated mice $(p<0.05)$. C, CD45 immunoreactivity was modestly and nonsignificantly attenuated in L-NBP-treated mice compared with vehicle control-treated mice. Values represent group mean $\pm \mathrm{SEM}$. $n=8-9$ mice per group. ${ }^{*} p<0.05$ versus vehicle control group.

A
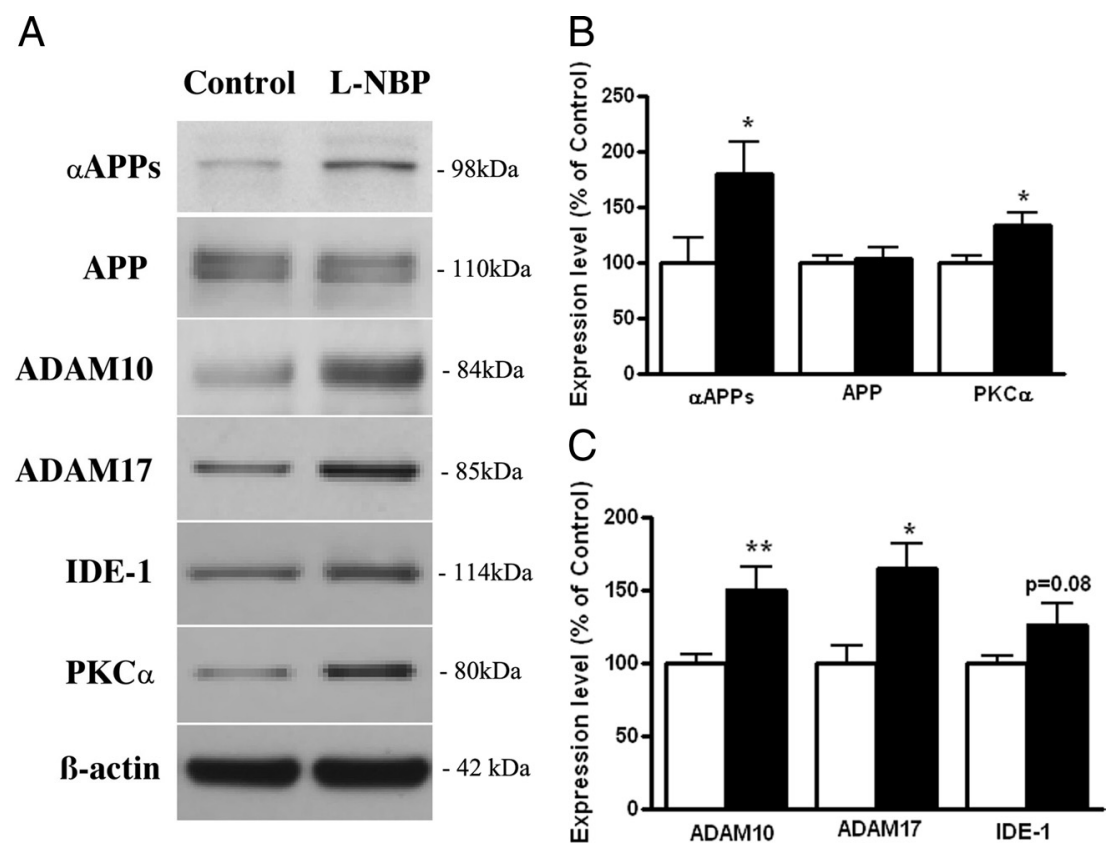

Figure 4. L-NBP treatment promoted $\alpha$ APPs release and elevated ADAM10, ADAM17, and PKC $\alpha$ levels in 3xTg-AD mice. $A$, Representative Western blots of $\alpha$ APPS, APP, ADAM10, ADAM17, IDE-1, and PKC $\alpha$ in the brain homogenates of 3xTg-AD mice treated with vehicle control and L-NBP, respectively, are shown. $B, C$, Quantitative analysis of $\alpha \mathrm{APPS}, \mathrm{APP}$, and PKC $\alpha(\boldsymbol{B})$ and ADAM10, ADAM17, and IDE-1 (C). Quantified results were normalized to $\beta$-actin expression. Values were expressed as percentages compared with vehicle control mice (set to $100 \%$ ) and represented as group mean \pm SEM. $n=8-9$ mice per group. ${ }^{*} p<0.05$, ${ }^{* *} p<0.01$ versus vehicle control group. (recognizing the Ser202 and Thr205 residues), AT180 (recognizing the Thr231 residue), and PHF-1 (recognizing the Ser396 or Ser404 residues; gift from Dr. P. Davies, Albert Einstein College of Medicine, Bronx, NY). AT8, AT180, and PHF-1 immunoreactivities were found in scattered neurons and neuronal processes of the CA1 and dorsal subiculum in the vehicle control 3xTg-AD mice (supplemental Fig. $1 A$, available at www. jneurosci.org as supplemental material). L-NBP treatment nonsignificantly decreased AT8 immunoreactivity by $35.5 \%$ compared with vehicle control treatment ( $p=0.35$ ) (supplemental Fig. $1 B$, available at www.jneurosci.org as supplemental material). AT180 and PHF-1 immunoreactivities were similar between L-NBPand vehicle control mice (supplemental Fig. $1 C, D$, available at www.jneurosci.org as supplemental material) and, therefore, unaffected by L-NBP treatment.

\section{L-NBP increased $\alpha$ APPs release and diminished $A \boldsymbol{\beta}$ generation in APP-transfected SK-N-SH cells}

To validate our in vivo studies, we performed in vitro studies to determine whether L-NBP treatment could promote non-amyloidogenic APP processing and $\alpha$-secretase proteolysis and impact $A \beta$ levels in neuroblastoma SK-N-SH APPwt cells. First, we examined the effect of L-NBP on regulating the release of $\alpha \mathrm{APPs}$ into the conditioned media in SK-N-SH APPwt cells. Western blot with antibody R1736 revealed that, after a $24 \mathrm{~h}$ treatment of the cells with L-NBP, $\alpha$ APPs secretion was elevated in a concentration-dependent manner. At the dose of $0.1 \mu \mathrm{M}, \mathrm{L}-\mathrm{NBP}$ increased $\alpha$ APPs release by $75 \%(p<0.05)$. The maximal effect of L-NBP was observed at a concentration of $10 \mu \mathrm{M}$, which resulted in a twofold increase in $\alpha$ APPs levels compared with the control $(p<$ 0.001) (Fig. 5A,B). These data suggest that L-NBP mediated APP processing toward the non-amyloidogenic pathway. Next, we evaluated the effect of L-NBP on cellular APP levels after $24 \mathrm{~h}$ of treatment. Whole-cell lysates were analyzed by Western blot by using an APP antibody, C8. L-NBP treatment had no effect on APP steady-state levels, further suggesting that L-NBP affected APP processing but not APP synthesis (Fig. $5 A, C$ ).

ELISA results showed that $\mathrm{A} \beta_{x-40}, \mathrm{~A} \beta_{x-42}$, and $A \beta_{1 \text {-total }}$ production were dose dependently reduced after $24 \mathrm{~h}$ of treatment with L-NBP. Particularly at the high concentration of $10 \mu \mathrm{M}$ L-NBP, $\mathrm{A} \beta_{x-40}, \mathrm{~A} \beta_{x-42}$, and $\mathrm{A} \beta_{1 \text {-total }}$ levels were significantly reduced by 
$25 \%(p<0.01), 34 \%(p<0.05)$, and $31 \%$ $(p<0.05)$, respectively (Fig. $5 D-F)$. Cell viability was examined after $24 \mathrm{~h}$ of incubation with L-NBP at $0-10 \mu \mathrm{M}$, but L-NBP had no effect on cell viability (Fig. 5G). Cell proliferation and grow rates were unchanged by L-NBP treatment (data not shown). Thus, it appears that L-NBP was nontoxic to SK$\mathrm{N}$-SH APPwt cells, and the reduction in $\mathrm{A} \beta$ levels was not attributable to cell death.

Next, we chose C-terminal polyclonal antibodies to detect ADAM10 and ADAM17 expression at the cellular membrane. After $24 \mathrm{~h}$ incubation, L-NBP partially increased the ADAM10 and ADAM17 levels in a dose-dependent manner. However, the difference between L-NBP-treated cells and control cells did not reach significance (supplemental Fig. $2 A-D$, available at www.jneurosci.org as supplemental material). We speculated that L-NBP might regulate the activities of ADAMs at an earlier stage. To address this issue, the cells were preincubated with the ADAM17 inhibitor tumor necrosis factor- $\alpha$ protease inhibitor-2 (TAPI-2) at $10 \mu \mathrm{M}$ and the ADAM10 inhibitor matrix metalloproteinase-9 (MMP-9)/ MMP-13 at $2 \mu \mathrm{M}$ for $30 \mathrm{~min}$ and then coincubated with the inhibitors and 10 $\mu \mathrm{M}$ L-NBP for $24 \mathrm{~h}$. The results are shown in Figure 5, $H$ and $I$. L-NBP markedly enhanced $\alpha$ APPs release $(p<0.01)$. The ADAM10 and ADAM17 inhibitors blocked the L-NBP-mediated $\alpha$ APPs elevation ( $p<$ $0.05)$, further confirming that the effect of $\mathrm{L}-\mathrm{NBP}$ on APP processing is regulated via $\alpha$-secretase and that ADAM10 and ADAM17 are likely involved.

To determine whether PKC signaling is involved in the L-NBP-induced increase in $\alpha$ APPs release, we directly detected PKC $\alpha$ expression in the SK-N-SH APPwt cells. Incubation of L-NBP for $24 \mathrm{~h}$ dose dependently elevated PKC $\alpha$ levels, especially at the $10 \mu \mathrm{M}$ dose at which the increase was significant $(p<0.05)$ (Fig. 5J,K). A PKC signaling-specific inhibitor, GF109203X (2[1-(3-dimethylaminopropyl)-1 $H$-indol-3yl]-3-(1 $H$-indol-3-yl)maleimide) $(2.5 \mu \mathrm{M})$, was used to preincubate the cells for $30 \mathrm{~min}$ before and throughout L-NBP treatment. $\alpha$ APPs release induced by L-NBP was significantly reduced by the PKC inhibitor, indicating that the PKC signaling pathway may be involved in L-NBP-induced $\alpha$ APPs release $(p<0.001)$ (Fig. $5 L, M)$.

\section{Discussion}

L-NBP may be a promising candidate for the treatment of $\mathrm{AD}$ because it has been shown to alleviate the cognitive impairment induced by $\mathrm{A} \beta$ intracerebroventricular infusion in rats in vivo (Peng et al., 2009) and reduce $A \beta$-induced neuronal apoptosis in vitro (Peng et al., 2008). Until now, the actual therapeutic value of $\mathrm{L}-\mathrm{NBP}$ on $\mathrm{AD}$ pathology and cognitive deficits has not been dem-
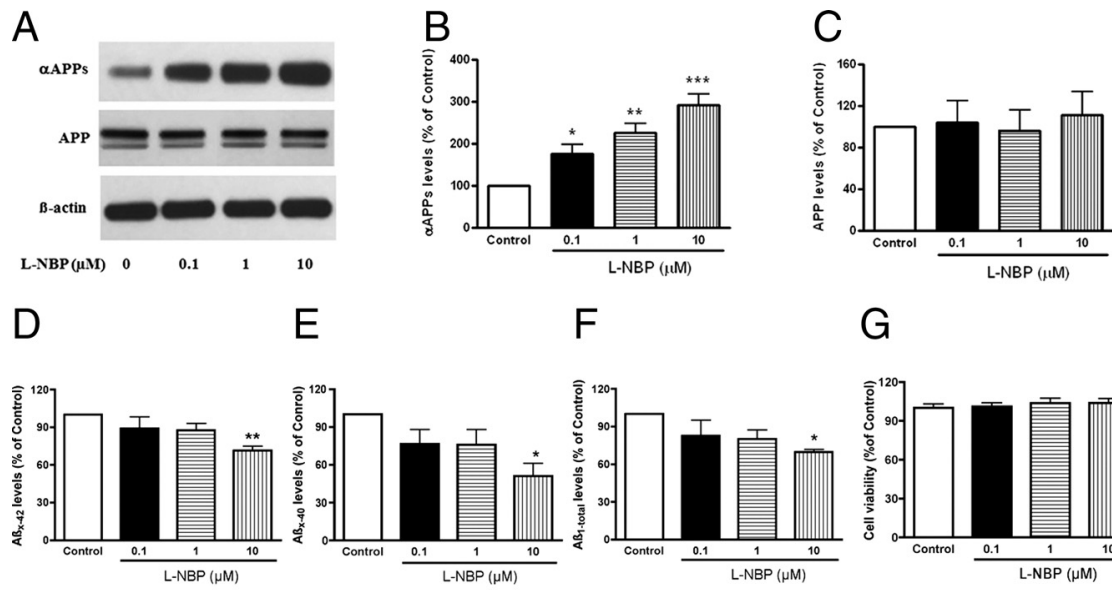

$\mathrm{F}$

G
$\mathrm{H}$

J

L

Figure 5. L-NBP increased the $\alpha$ APPs release, reduced A $\beta$ generation, and had no effect on full-length APP level and cell viability in cultured neuroblastoma SK-N-SH APPwt cells. $\alpha$-Secretase and PKC $\alpha$ may be involved in L-NBP-regulated APP processing toward the non-amyloidogenic pathway. Cells were incubated with L-NBP at each of three concentrations $(0.1,1$, or $10 \mu \mathrm{M})$ or without L-NBP (control) for $24 \mathrm{~h}$. A, Media were collected, and $\alpha A P P s$ and steady-state levels of APP were detected with polyclonal antibodies R1736 and C8, respectively, using Western blot. $B, C$, Quantitative analysis of the Western blot was expressed as a percentage of $\alpha$ APPs $(B)$ and APP $(\boldsymbol{C})$ from control cells. $\boldsymbol{D}-\boldsymbol{F}, A \beta_{x-42}, A \beta_{x-40}$, and $A \beta_{1 \text {-total }}$ levels of the medium were detected by specific ELISAs. L-NBP dose dependently reduced A $\beta$ levels. $G$, Cell viability was evaluated using a Cell Viability kit (MTT analysis). Cell viability of neuroblastoma cells was unchanged after L-NBP incubation. $\boldsymbol{H}, \mathbf{I}$, Cells were preincubated for $30 \mathrm{~min}$ with vehicle alone or with $10 \mu \mathrm{M}$ TAPI-2 or $2 \mu \mathrm{M}$ MMP-9/MMP-13 and then co-inhibited with the inhibitor with or without L-NBP for an additional $24 \mathrm{~h}$. The inhibitors of TACE/ADAM17 and ADAM10 partially inhibited L-NBP-induced $\alpha$ APPs secretion. $\boldsymbol{J}, \boldsymbol{K}, \mathrm{L}-\mathrm{NBP}$ increased PKC $\alpha$ levels dose dependently. L, M, A specific inhibitor of PKC (GF109203X) reduced L-NBP-induced $\alpha$ APPs release in neuroblastoma SK-N-SH APPwt cells. Cells were preincubated with the PKC inhibitor for $30 \mathrm{~min}$ and then with the inhibitor with or without L-NBP for an additional $24 \mathrm{~h} . \alpha$ APPs in the media was detected by polyclonal APP antibody, R1736, using Western blot. Results are shown as the mean \pm SEM and represent six independent experiments. ${ }^{*} p<0.05,{ }^{* *} p<0.01,{ }^{* * *} p<0.001$ versus control group or L-NBP group. onstrated. Our study demonstrates for the first time that L-NBP treatment by oral gavage reduced $\mathrm{A} \beta$ plaque deposition, gliosis, and oxidative stress and improved spatial learning and long-term memory deficits in 3xTg-AD mice.

A number of studies have shown that $\mathrm{A} \beta$ plaque deposition occur before or early in stages of neurodegeneration and behavioral changes in AD patients (Selkoe, 2001). Recently, soluble $\mathrm{A} \beta$ was demonstrated to induce spatial memory deficits in $\mathrm{AD}$ animal models (Billings et al., 2005; Lesné et al., 2006). Our results showed that L-NBP significantly improved spatial learning and long-term spatial memory deficits in 3xTg-AD mice. In the shortterm memory probe trial ( $2 \mathrm{~h}$ after the last training session), 
L-NBP-treated mice performed better than chance but not significantly better than vehicle control mice. The same mice showed significantly better learning on the same day (day 5) compared with the vehicle controls. The discrepancy in these results could be attributable to treatment differences in learning versus memory (although there was a significant treatment effect in long-term memory on day 7) and more variability in the $2 \mathrm{~h}$ probe trial and/or the small number of mice in each group.

L-NBP treatment decreased aggregated TBS-T-soluble and guanidine-soluble $\mathrm{A} \beta_{1 \text {-total }}$ levels in brain homogenates as well as R1282-immunoreactive $A \beta$ plaque deposition but not Thio $S$ fibrillar plaques in the brains of $3 x T g-A D$ mice. The $\mathrm{A} \beta$ pellets in the TBST-soluble and guanidine-soluble fractions include diffuse and aggregated, fibrillar plaque material. However, Thio S staining detects mainly $\beta$-pleated sheet, fibrillar amyloid plaques, whereas R1282 detects both diffuse and fibrillar $A \beta$ deposits. Thus, we believe that L-NBP reduced diffuse $A \beta$ plaques preferentially over fibrillar, compacted $\mathrm{A} \beta$ plaques that were relatively sparse to begin with in our mice. L-NBP showed a nonsignificant but strong trend for reducing soluble $A \beta$ levels and, therefore, may also have an effect on potentially neurotoxic soluble $\mathrm{A} \beta$ oligomers. L-NBP reduced $\mathrm{A} \beta_{1 \text {-total }}$ but did not change $\mathrm{A} \beta_{x-40} /$ $\mathrm{A} \beta_{x-42}$ levels. The discrepancy suggests the possibility that L-NBP may have an effect on the N-terminal cleavage of $\mathrm{A} \beta$ by $\beta$-secretase (BACE). A previous study demonstrated that BACE1 prefers the $\mathrm{A} \beta_{1}$ site, whereas BACE2 prefers internal cleavage sites within $A \beta_{1-40}$, such as the $A \beta_{19}$ or $A \beta_{20}$ sites and the $A \beta_{34}$ site (Shi et al., 2003). Investigation of the effects of L-NBP on BACE cleavage of APP is underway in long-term L-NBP prevention and treatment studies in 3xTg-AD mice in our laboratory.

A recent report (Hirata-Fukae et al., 2008) described a slowing of the progression of pathology in the $3 \mathrm{xTg}$ - $\mathrm{AD}$ model compared with the initial reports. We, too, have made the same observation. At the time we initiated our study, the 10- to 11-month-old mice in our colony had only very low amounts of plaque deposition, most of which was limited to the subiculum. We did not perform water maze testing on 10- to 11-month-old mice at that time, so we are unable to confirm whether the mice were already cognitively impaired as suggested by previous publications. Thus, it is possible that the beneficial effects of L-NBP on cognitive impairment and $\mathrm{A} \beta$ deposition may have been attributable to prevention or delaying of the pathological and cognitive changes rather than reversing preexisting pathology and/or cognitive deficits.

It appears that the effect by L-NBP of lowering cerebral $\mathrm{A} \beta$ accumulation may be attributable to directing APP processing toward a non-amyloidogenic pathway. Our study confirmed that L-NBP enhanced $\alpha$ APPs release and precluded A $\beta$ generation. $\alpha \mathrm{APP}$ has been shown to be beneficial for memory function and possesses neuroprotective and neurotrophic properties (Mattson, 1997). It is possible that $\alpha$ APPs derived from L-NBP-mediated APP processing may serve as a neuroprotective agent and contribute to the long-term benefit of L-NBP on memory in 3xTg-AD mice.

Members of the ADAM family have been put forward as candidate $\alpha$-secretases (Buxbaum et al., 1998). ADAM10 and tumor necrosis factor- $\alpha$ converting enzyme (TACE)/ADAM17 are considered likely candidates for $\alpha$-secretase APP cleavage (Lammich et al., 1999; Nunan and Small, 2000). Our study shows that L-NBP long-term treatment promoted non-amyloidogenic APP processing in vitro and in vivo, by promoting $\alpha$-secretase cleavage of APP. In our $3 x T g-A D$ mice study, ADAM10 and TACE protein levels were significantly elevated in L-NBP-treated mice. In SKN-SH APPwt cells, L-NBP led to a trend for increased ADAM10 and TACE protein levels. We speculated that the effect of L-NBP on ADAM10 and TACE might occur at an early stage and gradually disappear. To understand the effects of ADAM10 and TACE clearly, we chose the selective, competitive inhibitors MMP-9/ MMP-13 and TAPI-2 to determine the role of ADAM10 and TACE on L-NBP-regulated $\alpha$ APPs release and found that the effects of L-NBP were partially inhibited. Together, these results indicate that ADAM10 and TACE may be involved in L-NBPinduced APP processing.

PKC messenger pathways have been shown to be involved in regulating the non-amyloidogenic processing of APP (Buxbaum et al., 1993; Hung et al., 1993), although not through APP phosphorylation (Hung and Selkoe, 1994). Instead, PKC seems to change $\alpha$-secretase activities or APP trafficking by protein phosphorylation (Koo, 1997; Skovronsky et al., 2000). In our study, the role of PKC $\alpha$ in the L-NBP-mediated increase in $\alpha$ APPs release was demonstrated in vivo and in vitro. The long-term treatment of L-NBP significantly upregulated PKC $\alpha$ levels in the brains of 3xTg-AD mice. This effect was confirmed by treatment of SK-N-SH APP cells with L-NBP. In addition, the PKC-specific inhibitor GF109203X partially inhibited L-NBP-induced $\alpha$ APPs release, suggesting that the $\mathrm{PKC}$ pathway may be involved in L-NBP-regulated $\alpha$ APPs release.

$\mathrm{A} \beta$ reduction could also occur via increased $\mathrm{A} \beta$ clearance mechanisms, such as upregulating expression of $A \beta$ cleaving enzymes, including IDE and neprilysin. Endogenous IDE is considered a major soluble protease involved in the degradation of $\mathrm{A} \beta$ in the brain. Here, L-NBP partially increased IDE expression in the treated $3 \times \mathrm{X}$-AD mice, but the difference was not significant $(p<0.08)$. Thus, L-NBP may have some potential to promote $\mathrm{A} \beta$ degradation by activating IDE, thereby lowering $\mathrm{A} \beta$ plaque deposition in brain, but a larger study is needed to further assess this possibility.

Oxidative stress is one of the earliest events in the development and progression of AD pathology (Nunomura et al., 2001). In $3 \mathrm{xTg}-\mathrm{AD}$ mice, vitamin $\mathrm{E}$ and glutathione, two non-enzymatic antioxidants, were shown to be decreased and the levels of several lipid peroxidation markers were increased before the appearance of A $\beta$ plaques and neurofibrillary tangles (Resende et al., 2008). In the current study, we found that L-NBP significantly reduced the level of lipid peroxidation. In addition, L-NBP modestly and nonsignificantly increased the activities of the total antioxidant enzymes and catalase (data not shown). Our data suggest that the antioxidant effects of L-NBP may be beneficial and act synergistically with other mechanisms for the treatment of AD. Inflammation has long been hypothesized to play a critical role in $\mathrm{AD}$ (Griffin, 2006). In 3xTg-AD mice, activation of microglia and astrocytes was markedly enhanced and coincided with the appearance of cognitive deficits and synaptic dysfunction in these mice (Oddo et al., 2003b; Billings et al., 2005; Janelsins et al., 2005). Activation of microglia and astrocytes was reduced in L-NBP-treated 3xTg-AD mice. The inhibitory effect of L-NBP on gliosis may be secondary to the lowering of the $A \beta$ plaque burden. However, L-NBP has been shown to have a direct antiinflammatory effect independent of A $\beta$ (Peng et al., 2007b). Additional studies of L-NBP on neuroinflammation are ongoing, but the anti-inflammatory effect of L-NBP demonstrated here provide additional evidence of the therapeutic potential of L-NBP for $\mathrm{AD}$.

Oddo et al. (2003b) reported that AT180- and AT8immunoreactive neurons were readily apparent between 12 and 15 months of age, and PHF-1 staining became evident by 18 months of age in $3 \times \mathrm{Tg}-\mathrm{AD}$ mice. In the present study, the 
3xTg-AD mice were 15 months of age at the time of they were killed. We observed only sparse staining of hyperphosphorylated tau, indicating that these mice were still in early stages of tau pathology. At this stage, L-NBP seemed to have minimal (AT8) or no (AT180 and PHF-1) effect on tau protein hyperphosphorylation. It is possible that the study ended too early to see major effects on tau pathology, such as the formation of PHF-1immunoreactive dystrophic neurites or neurofibrillary tangles. In addition, it is possible that L-NBP might delay rather than prevent tau pathology. A large study is underway to explore the long-term effects of L-NBP on tau pathology in older 3xTg-AD.

In conclusion, our data demonstrate that L-NBP was able to reduce cerebral $A \beta$ levels, glial activation, oxidative stress, and cognitive impairment in the $3 \mathrm{xTg}$-AD mouse model. In addition, we found that L-NBP regulated APP processing toward the nonamyloidogenic pathway and promoted $\alpha$ APPs release, thereby precluding $\mathrm{A} \beta$ generation. $\mathrm{L}-\mathrm{NBP}$ appears to be promising as a multitarget drug for the prevention and/or treatment of Alzheimer's disease.

\section{References}

Allinson TM, Parkin ET, Turner AJ, Hooper NM (2003) ADAMs family members as amyloid precursor protein alpha-secretases. J Neurosci Res 74:342-352.

Billings LM, Oddo S, Green KN, McGaugh JL, LaFerla FM (2005) Intraneuronal $\mathrm{A} \beta$ causes the onset of early Alzheimer's disease-related cognitive deficits in transgenic mice. Neuron 45:675-688.

Buxbaum JD, Koo EH, Greengard P (1993) Protein phosphorylation inhibits production of Alzheimer amyloid beta/A4 peptide. Proc Natl Acad Sci U S A 90:9195-9198.

Buxbaum JD, Liu KN, Luo Y, Slack JL, Stocking KL, Peschon JJ, Johnson RS, Castner BJ, Cerretti DP, Black RA (1998) Evidence that tumor necrosis factor alpha converting enzyme is involved in regulated alpha-secretase cleavage of the Alzheimer amyloid protein precursor. J Biol Chem 273:27765-27767.

Chang Q, Wang XL (2003) Effects of chiral 3-n-butylphthalide on apoptosis induced by transient focal cerebral ischemia in rats. Acta Pharmacol Sin 24:796-804.

Checler F (1995) Processing of the beta-amyloid precursor protein and its regulation in Alzheimer's disease. J Neurochem 65:1431-1444.

Chen G, Chen KS, Knox J, Inglis J, Bernard A, Martin SJ, Justice A, McConlogue L, Games D, Freedman SB, Morris RG (2000) A learning deficit related to age and beta-amyloid plaques in a mouse model of Alzheimer's disease. Nature 408:975-979.

Chen M, Fernandez HL (2004) Stimulation of beta-amyloid precursor protein alpha-processing by phorbol ester involves calcium and calpain activation. Biochem Biophys Res Commun 316:332-340.

Dong GX, Feng YP (2002) Effects of NBP on ATPase and anti-oxidant enzymes activities and lipid peroxidation in transient focal cerebral ischemic rats. Zhongguo Yi Xue Ke Xue Yuan Xue Bao 24:93-97.

Esch FS, Keim PS, Beattie EC, Blacher RW, Culwell AR, Oltersdorf T, McClure D, Ward PJ (1990) Cleavage of amyloid beta peptide during constitutive processing of its precursor. Science 248:1122-1124.

Etcheberrigaray R, Tan M, Dewachter I, Kuipéri C, Van der Auwera I, Wera S, Qiao L, Bank B, Nelson TJ, Kozikowski AP, Van Leuven F, Alkon DL (2004) Therapeutic effects of PKC activators in Alzheimer's disease transgenic mice. Proc Natl Acad Sci U S A 101:11141-11146.

Farris W, Mansourian S, Chang Y, Lindsley L, Eckman EA, Frosch MP, Eckman CB, Tanzi RE, Selkoe DJ, Guenette S (2003) Insulin-degrading enzyme regulates the levels of insulin, amyloid beta protein, and the $\beta$-amyloid precursor protein intracellular domain in vivo. Proc Natl Acad Sci U S A 100:4162-4167.

Gralle M, Botelho MG, Wouters FS (2009) Neuroprotective secreted amyloid precursor protein acts by disrupting amyloid precursor protein dimers. J Biol Chem 284:15016-15025.

Griffin WS (2006) Inflammation and neurodegenerative diseases. Am J Clin Nutr 83:470S-474S.

Haass C, Schlossmacher MG, Hung AY, Vigo-Pelfrey C, Mellon A, Ostaszewski BL, Lieberburg I, Koo EH, Schenk D, Teplow DB (1992) Amyloid beta- peptide is produced by cultured cells during normal metabolism. Nature 359:322-325.

Hirata-Fukae C, Li HF, Hoe HS, Gray AJ, Minami SS, Hamada K, Niikura T, Hua F, Tsukagoshi-Nagai H, Horikoshi-Sakuraba Y, Mughal M, Rebeck GW, LaFerla FM, Mattson MP, Iwata N, Saido TC, Klein WL, Duff KE, Aisen PS, Matsuoka Y (2008) Females exhibit more extensive amyloid, but not tau, pathology in an Alzheimer transgenic model. Brain Res 1216:92-103.

Hung AY, Selkoe DJ (1994) Selective ectodomain phosphorylation and regulated cleavage of beta-amyloid precursor protein. EMBO J 13:534-542.

Hung AY, Haass C, Nitsch RM, Qiu WQ, Citron M, Wurtman RJ, Growdon JH, Selkoe DJ (1993) Activation of protein kinase C inhibits cellular production of the amyloid beta-protein. J Biol Chem 268:22959-22962.

Itagaki S, McGeer PL, Akiyama H, Zhu S, Selkoe D (1989) Relationship of microglia and astrocytes to amyloid deposits of Alzheimer disease. J Neuroimmunol 24:173-182.

Jackson MJ (1999) An overview of methods for assessment of free radical activity in biology. Proc Nutr Soc 58:1001-1006.

Janelsins MC, Mastrangelo MA, Oddo S, LaFerla FM, Federoff HJ, Bowers WJ (2005) Early correlation of microglial activation with enhanced tumor necrosis factor-alpha and monocyte chemoattractant protein-1 expression specifically within the entorhinal cortex of triple transgenic Alzheimer's disease mice. J Neuroinflammation 2:23.

Johnson-Wood K, Lee M, Motter R, Hu K, Gordon G, Barbour R, Khan K, Gordon M, Tan H, Games D, Lieberburg I, Schenk D, Seubert P, McConlogue L (1997) Amyloid precursor protein processing and A beta42 deposition in a transgenic mouse model of Alzheimer disease. Proc Natl Acad Sci U S A 94:1550-1555.

Kang J, Lemaire HG, Unterbeck A, Salbaum JM, Masters CL, Grzeschik KH, Multhaup G, Beyreuther K, Müller-Hill B (1987) The precursor of Alzheimer's disease amyloid A4 protein resembles a cell-surface receptor. Nature 325:733-736.

Kinouchi T, Sorimachi H, Maruyama K, Mizuno K, Ohno S, Ishiura S, Suzuki K (1995) Conventional protein kinase C (PKC)-alpha and novel PKC epsilon, but not -delta, increase the secretion of an N-terminal fragment of Alzheimer's disease amyloid precursor protein from PKC cDNA transfected 3Y1 fibroblasts. FEBS Lett 364:203-206.

Koo EH (1997) Phorbol esters affect multiple steps in beta-amyloid precursor protein trafficking and amyloid beta-protein production. Mol Med 3:204-211.

Lammich S, Kojro E, Postina R, Gilbert S, Pfeiffer R, Jasionowski M, Haass C, Fahrenholz F (1999) Constitutive and regulated $\alpha$-secretase cleavage of Alzheimer's amyloid precursor protein by a disintegrin metalloprotease. Proc Natl Acad Sci U S A 96:3922-3927.

Lesné S, Koh MT, Kotilinek L, Kayed R, Glabe CG, Yang A, Gallagher M, Ashe $\mathrm{KH}$ (2006) A specific amyloid-beta protein assembly in the brain impairs memory. Nature 440:352-357.

Maier M, Peng Y, Jiang L, Seabrook TJ, Carroll MC, Lemere CA (2008) Complement C3 deficiency leads to accelerated amyloid beta plaque deposition and neurodegeneration and modulation of the microglia/macrophage phenotype in amyloid precursor protein transgenic mice. J Neurosci 28:6333-6341.

Matsuoka Y, Picciano M, Malester B, LaFrancois J, Zehr C, Daeschner JM, Olschowka JA, Fonseca MI, O'Banion MK, Tenner AJ, Lemere CA, Duff K (2001) Inflammatory responses to amyloidosis in a transgenic mouse model of Alzheimer's disease. Am J Pathol 158:1345-1354.

Mattson MP (1997) Cellular actions of beta-amyloid precursor protein and its soluble and fibrillogenic derivatives. Physiol Rev 77:1081-1132.

Mattson MP, Cheng B, Culwell AR, Esch FS, Lieberburg I, Rydel RE (1993) Evidence for excitoprotective and intraneuronal calcium-regulating roles for secreted forms of the beta-amyloid precursor protein. Neuron 10:243-254.

Morris R (1984) Developments of a water-maze procedure for studying spatial learning in the rat. J Neurosci Methods 11:47-60.

Nitsch RM, Slack BE, Wurtman RJ, Growdon JH (1992) Release of Alzheimer amyloid precursor derivatives stimulated by activation of muscarinic acetylcholine receptors. Science 258:304-307.

Nunan J, Small DH (2000) Regulation of APP cleavage by alpha-, beta- and gamma-secretases. FEBS Lett 483:6-10.

Nunomura A, Perry G, Aliev G, Hirai K, Takeda A, Balraj EK, Jones PK, Ghanbari H, Wataya T, Shimohama S, Chiba S, Atwood CS, Petersen RB, Smith MA (2001) Oxidative damage is the earliest event in Alzheimer disease. J Neuropathol Exp Neurol 60:759-767. 
Oddo S, Caccamo A, Kitazawa M, Tseng BP, LaFerla FM (2003a) Amyloid deposition precedes tangle formation in a triple transgenic model of Alzheimer's disease. Neurobiol Aging 24:1063-1070.

Oddo S, Caccamo A, Shepherd JD, Murphy MP, Golde TE, Kayed R, Metherate R, Mattson MP, Akbari Y, LaFerla FM (2003b) Triple-transgenic model of Alzheimer's disease with plaques and tangles: intracellular $A \beta$ and synaptic dysfunction. Neuron 39:409-421.

Peng Y, Zeng X, Feng Y, Wang X (2004) Antiplatelet and antithrombotic activity of L-3-n-butylphthalide in rats. J Cardiovasc Pharmacol 43:876-881.

Peng Y, Xu SF, Wang L, Feng YP, Wang XL (2005) Effect of- L-3-nbutylphthalide on cerebral infarct volume in the transient cerebral ischemia rats. Chin New Drug 14:420-423.

Peng Y, Jiang L, Lee DY, Schachter SC, Ma Z, Lemere CA (2006) Effects of huperzine A on amyloid precursor protein processing and beta-amyloid generation in human embryonic kidney 293 APP Swedish mutant cells. J Neurosci Res 84:903-911.

Peng Y, Lee DY, Jiang L, Ma Z, Schachter SC, Lemere CA (2007a) Huperzine A regulates amyloid precursor protein processing via protein kinase $\mathrm{C}$ and mitogen-activated protein kinase pathways in neuroblastoma SK-N-SH cells over-expressing wild type human amyloid precursor protein 695 . Neuroscience 150:386-395.

Peng Y, Xu S, Chen G, Wang L, Feng Y, Wang X (2007b) L-3-nButylphthalide improves cognitive impairment induced by chronic cerebral hypoperfusion in rats. J Pharmacol Exp Ther 321:902-910.

Peng Y, Xing C, Lemere CA, Chen G, Wang L, Feng Y, Wang X (2008) L-3-n-butylphthalide ameliorates beta-amyloid-induced neuronal toxicity in cultured neuronal cells. Neurosci Lett 434:224-229.

Peng Y, Xing C, Xu S, Lemere CA, Chen G, Liu B, Wang L, Feng Y, Wang X (2009) L-3-n-butylphthalide improves cognitive impairment induced by intracerebroventricular infusion of amyloid- $\beta$ peptide in rats. Eur J Pharmacol 621:38-45.

Resende R, Moreira PI, Proença T, Deshpande A, Busciglio J, Pereira C, Oliveira CR (2008) Brain oxidative stress in a triple-transgenic mouse model of Alzheimer disease. Free Radic Biol Med 44:2051-2057.

Selkoe DJ (1994) Normal and abnormal biology of the beta-amyloid precursor protein. Annu Rev Neurosci 17:489-517.

Selkoe DJ (2001) Alzheimer's disease: genes, proteins, and therapy. Physiol Rev 81:741-766.

Shi XP, Tugusheva K, Bruce JE, Lucka A, Wu GX, Chen-Dodson E, Price E, Li
Y, Xu M, Huang Q, Sardana MK, Hazuda DJ (2003) Beta-secretase cleavage at amino acid residue 34 in the amyloid beta peptide is dependent upon gamma-secretase activity. J Biol Chem 278:21286-21294.

Shoji M, Golde TE, Ghiso J, Cheung TT, Estus S, Shaffer LM, Cai XD, McKay DM, Tintner R, Frangione B (1992) Production of the Alzheimer amyloid beta protein by normal proteolytic processing. Science 258:126-129.

Sisodia SS, Koo EH, Beyreuther K, Unterbeck A, Price DL (1990) Evidence that beta-amyloid protein in Alzheimer's disease is not derived by normal processing. Science 248:492-495.

Skovronsky DM, Moore DB, Milla ME, Doms RW, Lee VM (2000) Protein kinase C-dependent alpha-secretase competes with beta-secretase for cleavage of amyloid-beta precursor protein in the trans-golgi network. J Biol Chem 275:2568-2575.

Slack BE, Ma LK, Seah CC (2001) Constitutive shedding of the amyloid precursor protein ectodomain is up-regulated by tumor necrosis factor- $\alpha$ converting enzyme. Biochem J 357:787-794.

Small CI, Lyles GA, Breen KC (2005) Lipopolysaccharide stimulates the secretion of the amyloid precursor protein via a protein kinase C-mediated pathway. Neurobiol Dis 19:400-406.

Smith-Swintosky VL, Pettigrew LC, Craddock SD, Culwell AR, Rydel RE, Mattson MP (1994) Secreted forms of beta-amyloid precursor protein protect against ischemic brain injury. J Neurochem 63:781-784.

Turner PR, Bourne K, Garama D, Carne A, Abraham WC, Tate WP (2007) Production, purification and functional validation of human secreted amyloid precursor proteins for use as neuropharmacological reagents. J Neurosci Methods 164:68-74.

Wallace WC, Akar CA, Lyons WE (1997) Amyloid precursor protein potentiates the neurotrophic activity of NGF. Brain Res Mol Brain Res 52:201-212.

Walsh DM, Klyubin I, Fadeeva JV, Cullen WK, Anwyl R, Wolfe MS, Rowan MJ, Selkoe DJ (2002) Naturally secreted oligomers of amyloid beta protein potently inhibit hippocampal long-term potentiation in vivo. Nature 416:535-539.

Xu H, Feng Y (1999) Effects of d-3-n-butylphthalide (NBP) on pial arterioles in focal cerebral ischemia rats. Acta Pharmacol Sin 34:172-175.

Xu HL, Feng YP (2000) Inhibitory effects of chiral 3-n-butylphthalide on inflammation following focal ischemic brain injury in rats. Acta Pharmacol Sin 21:433-438. 